Article

\title{
Bioinspired Green Synthesis of Chitosan and Zinc Oxide Nanoparticles with Strong Antibacterial Activity against Rice Pathogen Xanthomonas oryzae pv. oryzae
}

\author{
Yasmine Abdallah 1,2,+, Mengju Liu ${ }^{1,+}$, Solabomi Olaitan Ogunyemi ${ }^{1}$, Temoor Ahmed ${ }^{1}$, \\ Hatem Fouad $^{3,4}{ }^{(\mathbb{D})}$, Amro Abdelazez ${ }^{5}\left(\mathbb{D}\right.$, Chenqi Yan ${ }^{6}$, Yong Yang ${ }^{7}$, Jianping Chen ${ }^{6,7, *}$ and \\ $\operatorname{Bin~} \mathrm{Li}^{1, *(D)}$
}

1 State Key Laboratory of Rice Biology and Ministry of Agriculture Key Laboratory of Molecular Biology of Crop Pathogens and Insects, Institute of Biotechnology, Zhejiang University, Hangzhou 310058, China; yasmeen.abdallah@mu.edu.eg (Y.A.); 11716062@zju.edu.cn (M.L.); sollybombom@yahoo.com (S.O.O.); temoorahmed@zju.edu.cn (T.A.)

2 Department of Plant pathology, Minia University, Elminya 61519, Egypt

3 Ministry of Agriculture Key Laboratory of Agricultural Entomology, Institute of Insect Sciences, Zhejiang University, Hangzhou 310027, China; dr_hatem@zju.edu.cn

4 Department of Field Crop Pests, Plant Protection Research Institute, Agricultural Research Centre, Cairo 12619, Egypt

5 Department of Dairy Microbiology, Animal Production Research Institute, Agriculture Research Centre, Dokki, Giza 12618, Egypt; amorbiotic@yahoo.com

6 Institute of Plant Virology, Ningbo University, Ningbo 315211, China; yanchengqi@163.com

7 State Key Laboratory for Managing Biotic and Chemical Treats to the Quality and Safety of Agro-products, Institute of Virology and Biotechnology, Zhejiang Academy of Agricultural Sciences,

Hangzhou 310021, China; yangyong@zaas.ac.cn

* Correspondence: jpchen2001@126.com (J.C.); libin0571@zju.edu.cn (B.L.); Tel.: +86-571-88981412 (B.L.)

+ These authors contributed equally to this work.

Academic Editor: Helga Lichtenegger

Received: 3 September 2020; Accepted: 14 October 2020; Published: 19 October 2020

\begin{abstract}
Bacterial leaf blight caused by Xanthomonas oryzae pv. oryzae (Xoo) is one of the most devastating diseases, resulting in significant yield losses in rice. The extensive use of chemical antibacterial agents has led to an increase the environmental toxicity. Nanotechnology products are being developed as a promising alternative to control plant disease with low environmental impact. In the present study, we investigated the antibacterial activity of biosynthesized chitosan nanoparticles (CSNPs) and zinc oxide nanoparticles (ZnONPs) against rice pathogen Xoo. The formation of CSNPs and ZnONPs in the reaction mixture was confirmed by using UV-vis spectroscopy at 300-550 $\mathrm{nm}$. Moreover, CSNPs and ZnONPs with strong antibacterial activity against Xoo were further characterized by scanning and transmission electron microscopy, Fourier-transform infrared spectroscopy, and $\mathrm{X}$-ray diffraction. Compared with the corresponding chitosan and $\mathrm{ZnO}$ alone, CSNPs and ZnONPs showed greater inhibition in the growth of Xoo, which may be mainly attributed to the reduction in biofilm formation and swimming, cell membrane damage, reactive oxygen species production, and apoptosis of bacterial cells. Overall, this study revealed that the two biosynthesized nanoparticles, particularly CSNPs, are a promising alternative to control rice bacterial disease.
\end{abstract}

Keywords: antibacterial activity; chitosan nanoparticles; green synthesis; $\mathrm{ZnO}$ nanoparticles; tomato extract 


\section{Introduction}

Xanthomonas oryzae pv. oryzae (Xoo) causes bacterial leaf blight in rice, which leads to severe yield losses and consequently alters the food supplies [1]. The restriction of the use of chemical pesticides has become a pressing necessity due to its environmental toxicity. In general, bacterial diseases of plants are very difficult to control and cause significant annual losses on a global scale. The use of agricultural antibiotics such as streptomycin and oxytetracycline have been restricted in most counties to avoid the development of antibiotic resistance, but have been recently enhanced in others. Interestingly, nanotechnology products are promising and environmentally friendly strategies for the control of bacterial diseases. In particular, significant attention has been paid to the development of a plant or microbe-based synthesis of metal nanoparticles [2-5] due to toxic compounds that have been found on the surface of the nanoparticles through the chemical synthesis method [6,7].

Furthermore, a high number of polyphenols, especially flavonoids [8] in tomato make it a good candidate for synthesizing nanoparticles. In addition, unlike red tomatoes, green tomato is rich in alkaloids and contain a high amount of ascorbic acid $[9,10]$, the former was used as a biogenic stabilizer during the synthesis of chitosan nanoparticles (CSNPs) [11], while the latter plays a vital role in the production of zinc oxide nanoparticles (ZnONPs) [12]. Recently, numerous studies have demonstrated that the natural biopolymer chitosan and its derivative, as well as metal nanoparticles such as $\mathrm{Ag}, \mathrm{ZnO}, \mathrm{TiO}_{2}, \mathrm{MgO}$, and $\mathrm{CuO}$, have strong antibacterial activity against a variety of bacterial pathogen [13,14]. For example, Li et al. [15] reported that chitosan solution had strong antibacterial activity against Xanthomonas pathogenic bacteria isolated from Euphorbia pulcherrima, while the growth of the Xoo pathogen was significantly inhibited in our previous studies by the biosynthesized $\mathrm{MgO}$ nanoparticles [16], Ag nanoparticles [17,18] and ZnO nanoparticles [19]. Maruyama et al. [20] developed a system based on chitosan nanoparticles as carriers for the herbicides. Similarly, Campos et al. [21] prepared chitosan nanoparticles functionalized with $\beta$-cyclodextrin as a carrier system for botanical pesticides with a slower release profile.

The antimicrobial activity of the chitosan polymers and nanoparticles may be mainly attributed to their electric charge and high ability of adsorption as well as chemical reactions that allow them to interact efficiently with the bacterial cell membrane [22], while the inhibitory effect on the bacterial growth depends on their sizes and shapes as well as biological and structural properties [15]. Compared to the antibacterial activity of chitosan and metal nanoparticles alone, significant inhibition could be expected by the combination of chitosan with metal nanoparticles. Indeed, chitosan has also been studied as the main structural unit of nanomaterials due to its low toxicity, non-immunogenicity, and biodegradability. For example, [23] has synthesized and characterized chitosan/ $/ \mathrm{TiO}_{2}$ nanocomposite with antibacterial activity against $\mathrm{Xoo}$.

However, the concerns are rising on the residue of heavy metal ion in the natural environment, which makes it necessary to exclude the heavy metal ion during the control of Xoo by the combination of chitosan with nanoparticles. Interestingly, chitosan nanoparticles (CSNPs) not only have less toxic impact compared to the chitosan and metal nanoparticles alone [24-26], but also shows an inhibitory effect on the growth of several microorganisms $[27,28]$. Indeed, much attention has been directed toward the synthesis of CSNPs, which have been applied in many fields such as nanomedicine and biomedical engineering [29] due to its small size, high permeability, biocompatibility, biodegradability, and cost-effectiveness [30-32]. Thus, it can be expected that the Xoo can be effectively inhibited by the synthesis of CSNPs.

The purpose of this research was to biosynthesize CSNPs with strong antibacterial activity against the rice pathogen $\mathrm{Xoo}$, while $\mathrm{ZnO}$ nanoparticles (ZnONPs) were also biosynthesized as the positive control. Furthermore, the antibacterial activity of CSNPs was compared with that of chitosan, $\mathrm{ZnO}$ and $\mathrm{ZnO}$ nanoparticles alone. In addition, this study revealed the antibacterial mechanism of the biosynthesized CSNPs and ZnONPs against Xoo. 


\section{Materials and Methods}

\subsection{Preparation of Aqueous Green Tomato Extract}

Two grams of dried green tomatoes were placed in a $250 \mathrm{~mL}$ flask containing $200 \mathrm{~mL}$ deionized water and then boiled in a $60{ }^{\circ} \mathrm{C}$ water bath for $4 \mathrm{~h}$. After filtering twice with filter paper Whatman no. 1, the aqueous green tomato extract was directly used in the installation of CSNPs and ZnONPs.

\subsection{Green Synthesis of CSNPs and ZnONPS}

CSNPs and ZnONPs were synthesized according to the method of Dipali et al. [11] with minor modifications. In brief, the chitosan-TPP mixture was obtained by dissolving $0.8 \mathrm{~g}$ of sodium tripolyphosphate (TPP) (Aladdin Industrial Co., Shanghai, China) in $100 \mathrm{~mL}$ of chitosan solution, (Sinopharm chemical Regent Co., Ltd., China) which were prepared by adding about $1.5 \mathrm{~g}$ of chitosan $\left(\mathrm{C}_{6} \mathrm{H}_{11} \mathrm{NO}_{4}\right)_{\mathrm{n}}$ from shrimp shells, $\geq 75 \%$ (deacetylated) in $200 \mathrm{~mL}$ of $2 \%$ acetic acid solution and then stirring under continuous magnetic for $30 \mathrm{~min}$. Then, CSNPs were developed by adding $100 \mathrm{~mL}$ of the aqueous green tomato extract to $200 \mathrm{~mL}$ of a chitosan-TPP mixture dropwise under constant stirring for $30 \mathrm{~min}$. Similarly, ZnONPs were developed by adding $100 \mathrm{~mL}$ of the aqueous green tomato extract to $100 \mathrm{~mL}$ of $1 \mathrm{M} \mathrm{ZnO}$ (Sangon Biotech Co., Ltd., Shanghai, China) and then stirring at $60^{\circ} \mathrm{C}$ for $4 \mathrm{~h}$. After discarding the supernatant through centrifugation at 10,000 $\mathrm{g}$ for $20 \mathrm{~min}$, the pellets were washed with distilled water and then freeze-dried in ALPHA 1-2/LD-Plus vacuum to obtain the nanoparticles powders.

\subsection{Characterization of CSNPs and ZnONPs with Strong Antibacterial Activities}

\subsubsection{Analysis of UV-Vis Spectroscopy}

The highest peak absorption levels of CSNPs and ZnONPs were measured according to [33] by using UV-Vis spectroscopy at 300-550 nm (Shimadzu spectrometer, Kyoto, Japan) with a length of $1 \mathrm{~cm}$ path.

\subsubsection{TEM and SEM-EDS Observation}

The morphology of two types of the nanoparticles CSNPs and ZnONPs with strong antibacterial activity was observed using transmission electron microscopy (TEM) (JEM-1230, JEOL, Akishima, Japan), which was carried out as described by Ahmed et al. [34] by fixing the film of the sample in a grid box. Furthermore, the morphology of two types of nanoparticles was also observed according to the method of Ibrahim et al. [17] using scanned electron microscopy (SEM) (TM-1000, Hitachi, Tokyo, Japan). In brief, a film was prepared on a grid of carbon-coated copper by fixing a little amount of sample on the grid. The film on the SEM grid was dried by placing the grid under the mercury lamp for $5 \mathrm{~min}$. The device was connected with an energy dispersion spectrum (EDS) to confirm the presence of nanoparticles.

\subsubsection{FTIR Analysis}

The functional group of two types of the nanoparticles CSNPs and ZnONPs with strong antibacterial activity was determined based on the analysis of Fourier transform infrared spectroscopy (FTIR), which was carried out as described by Hossain et al. [35] by measuring the dried powder of the bio-synthesized two nanoparticles using Fourier transform infrared spectrometer (Vector 22, Bruker, Bremen, Germany) at a range of $500-4000 \mathrm{~cm}^{-1}$ regions at a resolution of $4 \mathrm{~cm}^{-1}$.

\subsubsection{XRD Analysis}

The quality of two types of the nanoparticles CSNPs and ZnONPs with strong antibacterial activity was determined using Siemens X-ray diffractometer (XRD), which was performed as described by Abdallah et al. [16] using drop coated film of dried powder of two types of the nanoparticles on 
glass slides with operating conditions of $45 \mathrm{kV}$ and $20 \mathrm{~mA}$ current with $\mathrm{Cu}-\mathrm{Ka}$ radiation as an X-ray source in the $20-80^{\circ}$ range at the $2 \theta$ angle.

\subsection{Antibacterial Activity and Mechanism of Action}

\subsubsection{Measurement of Bacterial Growth}

The antibacterial activity of CSNPs and ZnONPs against Xoo strain GZ 0005 was measured on a solid medium by using agar well diffusion assay, which was carried out as described by Perez et al. [36] with minor modifications. In brief, $200 \mu \mathrm{L}$ of overnight bacterial culture (approximately $1 \times 10^{8} \mathrm{CFU} / \mathrm{mL}$ ) was mixed with five $\mathrm{mL}$ of nutrient agar (NA) medium. About $50 \mu \mathrm{L}$ of dried nanoparticle solutions at different concentrations $(4.0,8.0$, and $16.0 \mu \mathrm{g} / \mathrm{mL})$ were poured at the $6 \mathrm{~mm}$ wells and incubated for $24 \mathrm{~h}$ at $30^{\circ} \mathrm{C}$. Then the inhibition zone around the well was measured. The antibacterial activity of CSNPs and ZnONPs against Xoo strain GZ 0005 was also examined on liquid broth, which was performed as described by [37]. The sterile tubes were incubated at $30{ }^{\circ} \mathrm{C}$ with shaking (180 rpm) containing $100 \mu \mathrm{L}$ of Xoo (approximately $1 \times 10^{8} \mathrm{CFU} / \mathrm{mL}$ ) in total $5 \mathrm{~mL}$ nutrient broth (Oxoid Ltd., Basingstoke, Hants, UK) to give different final concentrations of the nanoparticles $(4.0,8.0$, and $16.0 \mu \mathrm{g} / \mathrm{mL})$. The inhibitory effect on bacterial growth was determined by measuring the optical density at $\mathrm{OD}_{600} \mathrm{~nm}$ using a UV spectrophotometer after $48 \mathrm{~h}$ of incubation. The experiment was repeated twice, and each treatment had three replicates.

\subsubsection{Assay of Biofilm Formation}

Biofilm formation of Xoo strain GZ 0005 was determined in a 96-well plate by measuring the absorption value at $\mathrm{OD}_{570} \mathrm{~nm}$, according to Zhang et al. [38] with minor modifications. Briefly, each well was inoculated with $2 \mu \mathrm{L}$ of overnight bacterial suspension and $198 \mu \mathrm{L}$ NB broth supplement with CSNPs and ZnONPs with a final concentration of $0.0,4.0,8.0$, and $16.0 \mu \mathrm{g} / \mathrm{mL}$. The solutions were then incubated at $30^{\circ} \mathrm{C}$ for $48 \mathrm{~h}$ without shaking to form a biofilm. After removing the supernatant, the wells were added with crystal violet for staining, while acetic acid (33\%) was used to absorb crystal violet from the biofilm. Each treatment had at least six replicates and the experiment was repeated twice.

\subsubsection{Assay of Bacterial Motility}

Swimming motility on plates was detected according to the method [39]. In brief, ten microliters of an overnight culture of Xoo strain GZ 0005 were spotted onto $0.8 \%(w / v)$ NA media, which was pre-mixed with CSNPs and ZnONPs with a final concentration of $0.0,4.0,8.0$, and $16.0 \mu \mathrm{g} / \mathrm{mL}$. After three days of incubation at $30^{\circ} \mathrm{C}$, bacterial migration areas were measured. Each treatment was expressed in triplicates and the experiment was repeated twice.

\subsubsection{TEM Observation of Bacterial Cells}

Bacterial samples for TEM were prepared as described by Sun et al. [40] with some modifications. In brief, one mL of overnight bacterial culture of Xoo strain GZ 0005 was centrifuged at 11,000 rpm for $10 \mathrm{~min}$, and the obtained pellet was suspended in CSNPs and ZnONPs solutions with the final concentration of $16 \mu \mathrm{g} / \mathrm{mL}$, then incubated at $30^{\circ} \mathrm{C}$ for $4 \mathrm{~h}$. The samples were prepared following standard procedures for fixation and embedding then examined using an electron microscope H-7000FA (Hitachi, Tokyo, Japan) with an operating voltage of $75 \mathrm{kV}$.

\subsubsection{Flow Cytometric Analysis of Bacterial Cells}

CSNPs and ZnONPs induced apoptosis was observed by flow cytometry (GALLIOS BECKMAN COULTER, Krefeld, Germany). After centrifuging the overnight culture of Xoo strain GZ 0005 $\left(1 \times 10^{8} \mathrm{CFU} / \mathrm{mL}\right)$ for $5 \mathrm{~min}$ at $5000 \mathrm{~g}$, the bacterial pellets were treated with CSNPs and ZnONPs with 
the final concentration of $16.0 \mu \mathrm{g} / \mathrm{mL}$ for $4 \mathrm{~h}$, then propidium iodide (PI) was added as described by Cai et al. [41] to stain bacterial nuclei.

\subsubsection{Determination of Bacterial Reactive Oxygen Species (ROS)}

Intracellular ROS was determined using fluorescent probe 2, 7-dichlorofluorescein diacetate (DCFH-DA), which interact with ROS to form the fluorescence trapped inside the cell. In brief, one $\mathrm{mL}$ overnight culture of Xoo strain GZ $0005\left(1 \times 10^{8} \mathrm{CFU} / \mathrm{mL}\right)$ was centrifuged for $5 \mathrm{~min}$ at $5000 \mathrm{~g}$. Then, bacterial pellets were treated with CSNPs and ZnONPs with the final concentration of $16.0 \mu \mathrm{g} / \mathrm{mL}$ for $4 \mathrm{~h}$, respectively, while rotenone was also applied before two types of nanoparticles. The negative control was treated with sterile water. After washing with sterilized water three times, $10 \mu \mathrm{M} \mathrm{DCFH-DA}$ was added and then incubated in the dark at room temperature for $30 \mathrm{~min}$. Eventually, the samples were washed with sterilized water, and fluorescence was detected as described by Applerot et al. [42] using scanning confocal laser microscopy (SCLM) (Leica SP8, Germany).

\subsection{Statistical Analysis}

Data were subjected to analysis of variance (ANOVA) using SAS 2003 software (SAS Institute, Cary, NC, USA). A general linear model (GLM) procedure was used to check the significant differences among the main treatments. Individual comparisons between mean values were performed using Duncan's Method $(p<0.05)$.

\section{Results and Discussion}

\subsection{Biosynthesis of CSNPs and ZnONPs}

The biosynthesis procedure of two types of the nanoparticles by using dried green tomato extract as shown in the (Figure 1). Although peaks were not reached in both chitosan and $\mathrm{ZnO}$ solutions, there was a UV-Vis absorption spectra peak of 363 and $383 \mathrm{~nm}$, corresponding to CSNPs and ZnONPs, respectively (Figure 2). In contrast, $\mathrm{OH}$ et al. [43] reported that the absorption peak wavelength was at $320 \mathrm{~nm}$ in the UV region for CSNPs, while Akhtar et al. [44] reported that the UV-Vis absorption spectra peak of ZnONPs was about $400 \mathrm{~nm}$. However, in agreement with our study, Anumansirikul et al. [45] reported that the maximum peak for CSNPs was about 320-360 nm, whereas Ogunyemi et al. [19] found that the UV-vis spectra of zinc oxide nanoparticles showed a strong absorption band at 384, 380 and $386 \mathrm{~nm}$ for chamomile flower, olive leave, and red tomato fruit, respectively. As we know, the UV-Vis absorption spectrometry is an important technique for confirming the presence of nanoparticles in aquatic solution. Therefore, the inconsistent results in the UV-Vis absorption spectra peak may be mainly attributed to the difference in the procedure of biosynthesis of nanomaterials.

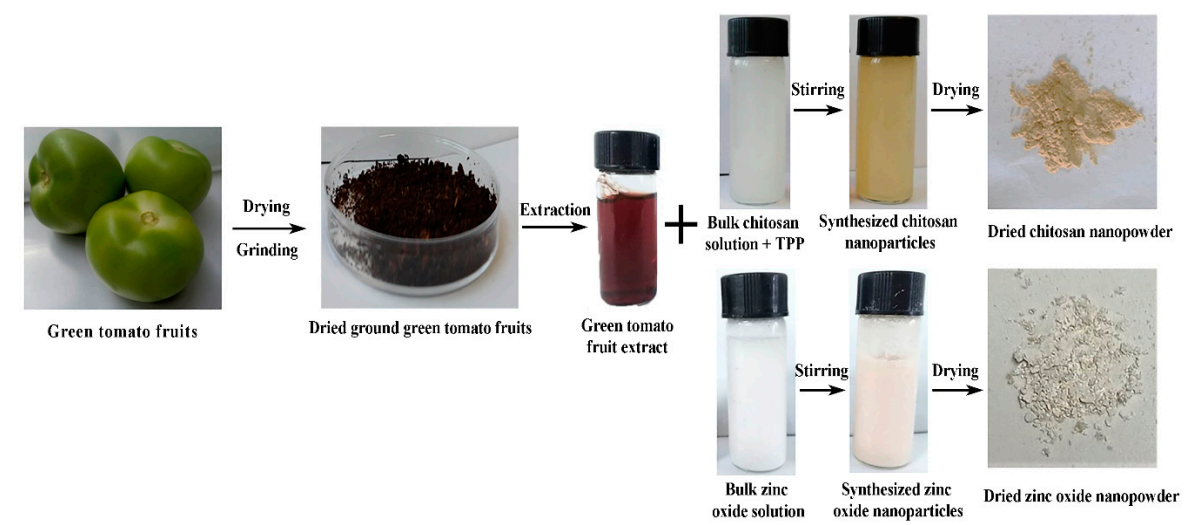

Figure 1. Schematic presentation of the preparation of chitosan nanoparticles (CSNPs) and zinc oxide nanoparticles (ZnONPs). 


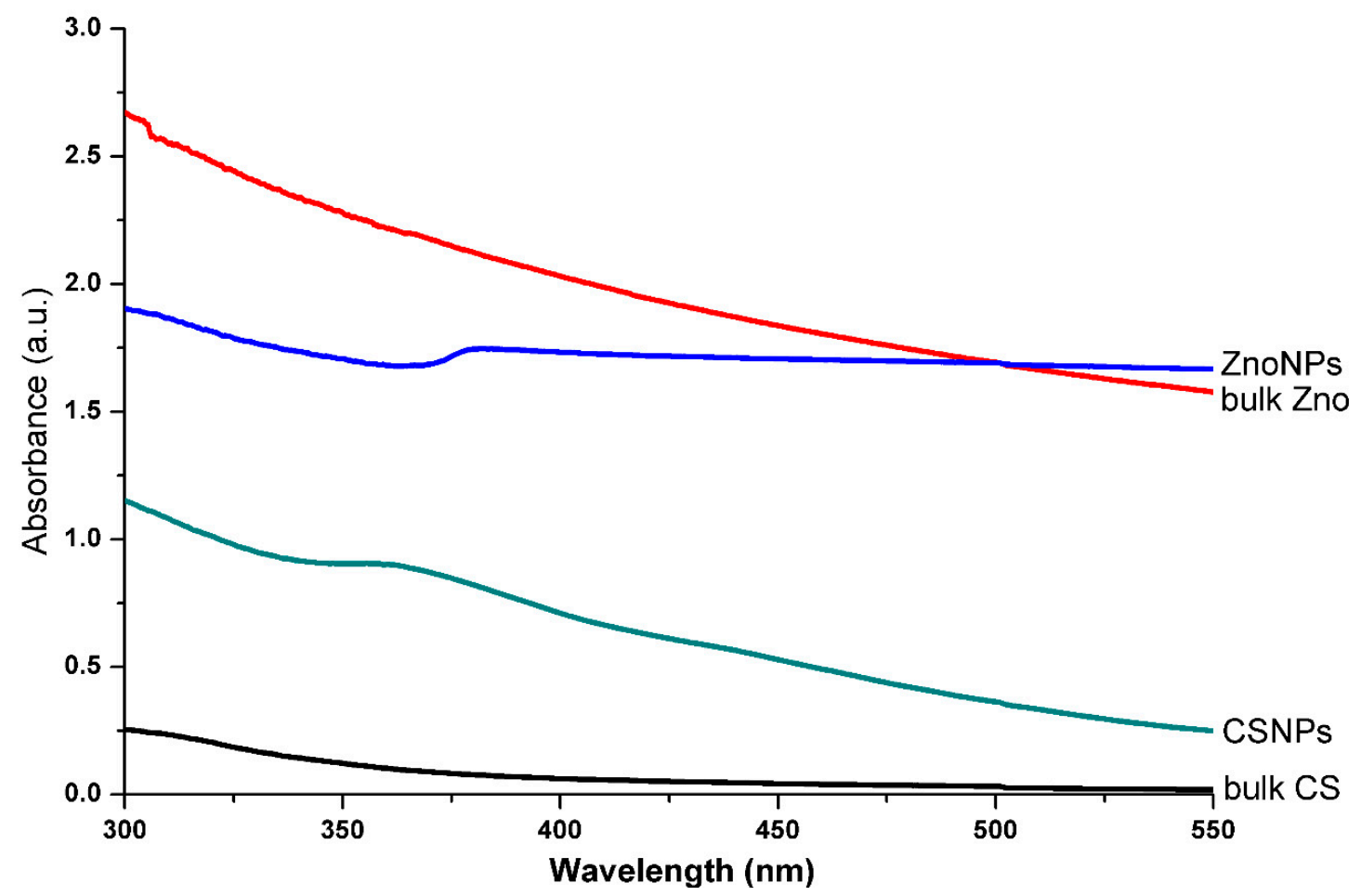

Figure 2. The UV-visible spectrum of bulk chitosan (CS), CSNPs, bulk ZnO, and ZnONPs solutions.

\subsection{Characterization of CSNPs and ZnONPs}

In order to effectively apply the two biosynthesized nanoparticles in agriculture, we further characterized the CSNPs and ZnONPs with strong antibacterial activity by TEM and SEM-EDS observation as well as FTIR and XRD analysis.

\subsubsection{TEM and SEM-EDS Observation}

The size and shape of nanoparticles play an important role in their antimicrobial activity against microbial pathogens, while smaller particle size can help nanoparticles easily enter the cell wall of microorganisms and increase the uptake of vehicles into the microbial cell [46]. Similar to the result of Parida et al. [47], the result of TEM and SEM images indicated that the biosynthesized CSNPs have a spherical shape with particle size ranging from 23.8 to $91.9 \mathrm{~nm}$ (Figure 3A,C). These results are in agreement with the data provided by Ilk et al. [48], who obtained similar results of CSNPs with spherical in shape and size ranging from 200 to $350 \mathrm{~nm}$ in diameter. In the case of ZnONPs, TEM and SEM analysis showed diverse polymorphic shapes such as spherical and hexagonal shapes with particle size ranging from 31.3 to $88.9 \mathrm{~nm}$ (Figure 3B,D). Similar results have been reported by Fu et al. [49], who synthesized hexagonal rod shape ZnONPs by using Plectranthus amboinicus leaf extract.

The elemental composition of the biosynthesized CSNPs and ZnONPs was confirmed by using EDS analysis. The EDS spectra revealed the percentage elemental composition of CSNPs, composed of carbon (54.38\%), oxygen (40.33\%), and phosphorus (5.29\%) (Figure 3E). In the case of ZnONPs, EDS peaks showed the percentage elemental composition, consisting of zinc $(80.11 \%)$ and oxygen $(19.89 \%)$ (Figure 3F). Furthermore, the elemental percentage of CSNPs in this study is similar to the report of Sotelo et al. [50], while the elemental percentage of ZnONPs of this study is similar to the report of Ogunyemi et al. [19]. In agreement with the result of Ali et al. [51], the EDS analysis obtained in this study shows that the samples prepared using aqueous green tomato extract contained pure ZnONPs. 

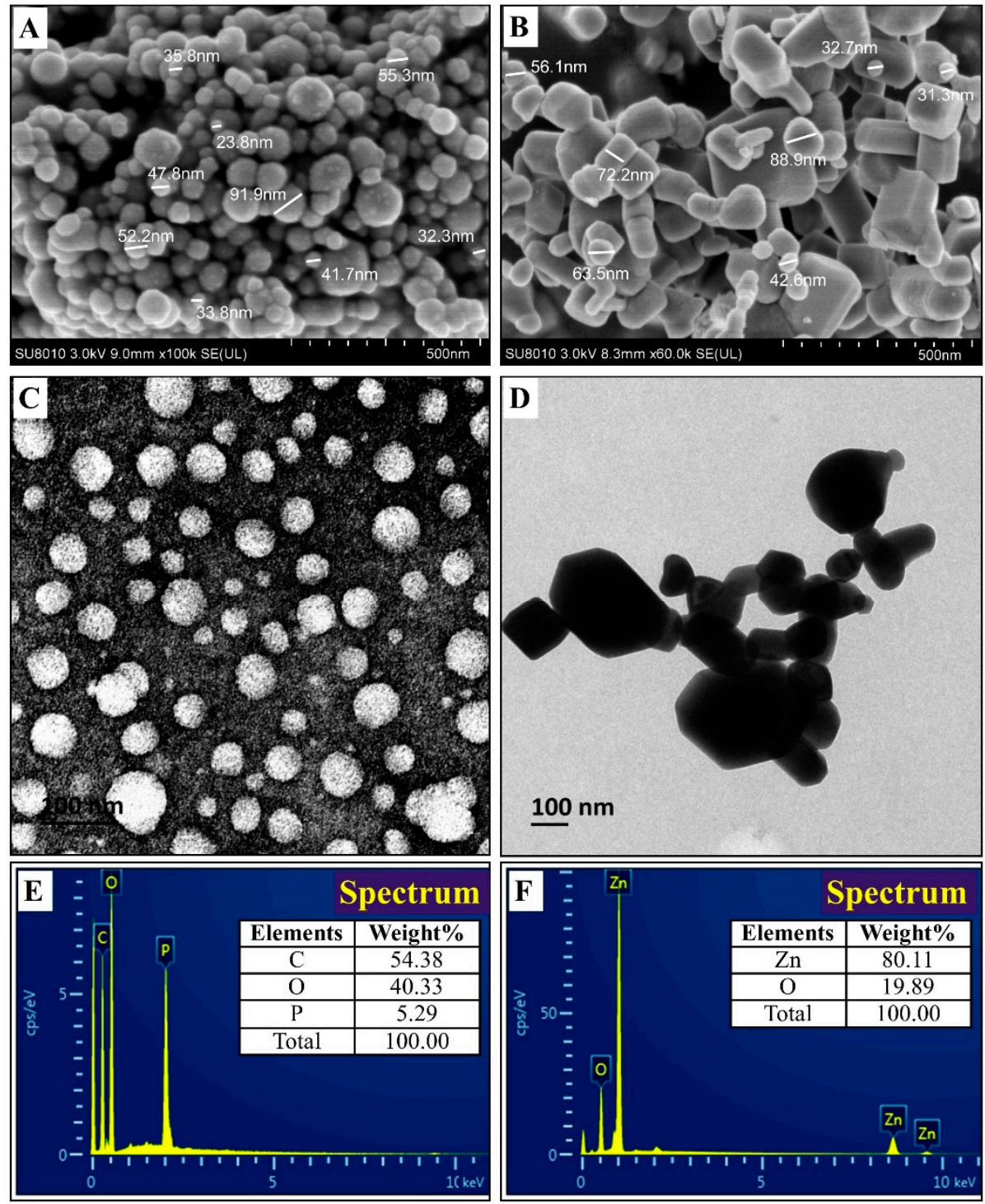

Figure 3. Characterization of the bio-synthesized by SEM analysis: (A) CSNPs; (B) ZnONPs, TEM analysis; (C) CSNPs; (D) ZnONPs and EDS; (E) CSNPs; (F) ZnONPs.

\subsubsection{FTIR Analysis}

The stability of green nanoparticles may be, at least partially, due to the capping proteins, which could have an additional advantage as antimicrobial agents. Indeed, the results of the FTIR spectrum provide an interpretation of the correlation between the absorption bands and the chemical compounds [52], which makes it possible for us to understand which biomolecules are involved in the increased antibacterial activity of two types of the nanoparticles. In the current study, the FTIR spectra of CSNPs showed multiple absorption peaks at 3416, 1634, 1539, 1395, 1076, and $889 \mathrm{~cm}^{-1}$ (Figure 4A). The absorption peaks at 3416 and $1634 \mathrm{~cm}^{-1}$ represented the $\mathrm{O}-\mathrm{H}$ stretching group of alcohol and $\mathrm{C}=\mathrm{C}$ stretching group of conjugated alkene, respectively. The absorption peaks observed at 1539 and $1395 \mathrm{~cm}^{-1}$ were due to the $\mathrm{N}-\mathrm{O}$ stretching group of a nitro compound and $\mathrm{O}-\mathrm{H}$ bending group of carboxylic acid, respectively. Furthermore, the peaks detected at 1076 and $889 \mathrm{~cm}^{-1}$ were attributed to the $\mathrm{C}-\mathrm{O}$ stretching group of primary alcohol and the $\mathrm{C}=\mathrm{C}$ bending group of alkene, respectively. In agreement with the data of this study, Salehizadeh et al. [53] reported that the FTIR spectra of CSNPs commonly show a peak at around $3416 \mathrm{~cm}^{-1}$ that corresponds to $\mathrm{O}-\mathrm{H}$ and $-\mathrm{NH}$ stretching vibration in chitosan. 

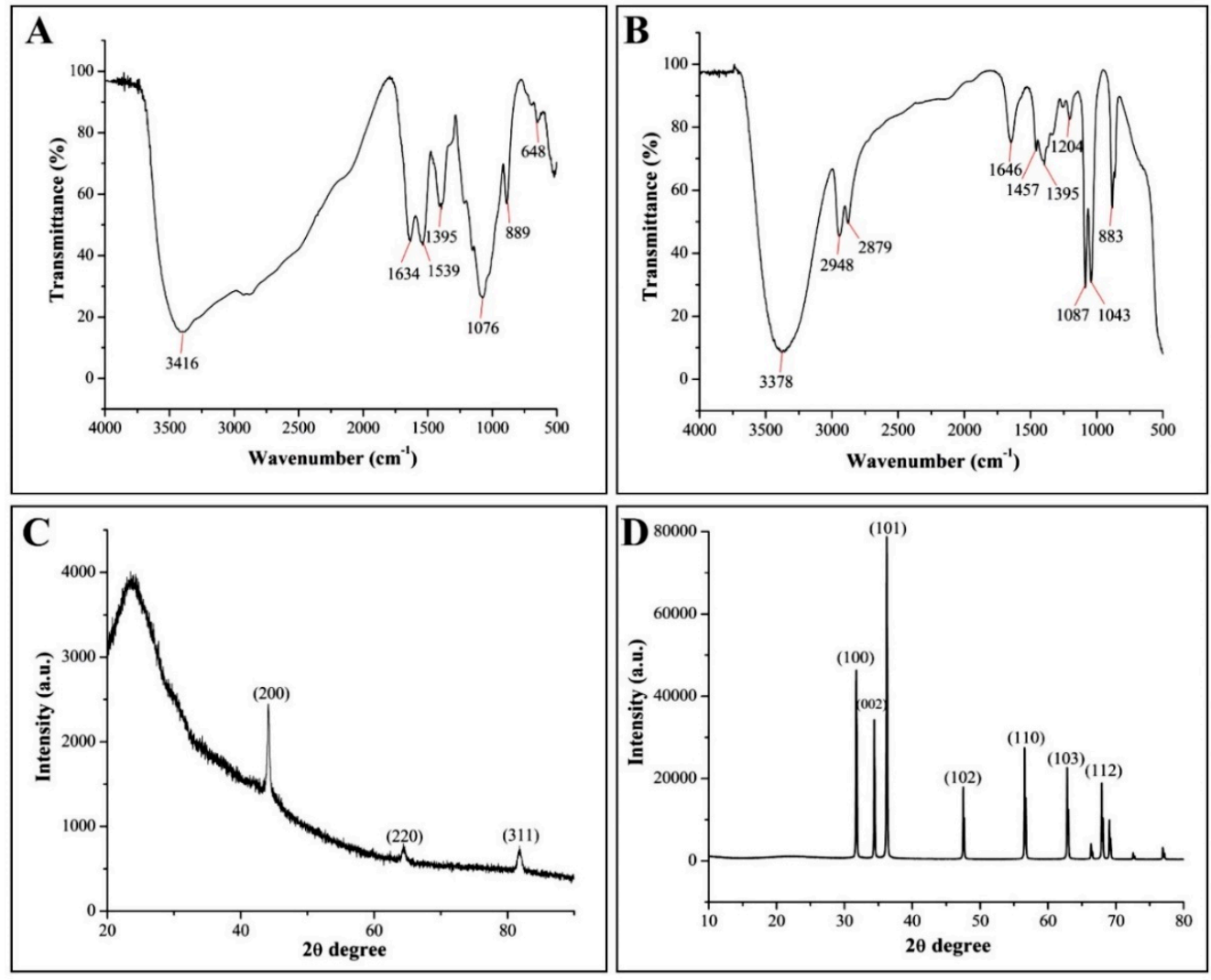

Figure 4. Fourier-transform infrared spectrum of (A) CSNPs and (B) ZnONPs. X-Rays diffraction patterns of (C) CSNPs and (D) ZnONPs.

In the case of ZnONPs, FTIR analysis indicated several absorption peaks at 3378, 2948, 2879, 1646, $1457,1395,1204,1078$, and $1043 \mathrm{~cm}^{-1}$, together with a weak peak at $889 \mathrm{~cm}^{-1}$, showing the complexity in capping pattern (Figure 4B). The FTIR peaks of ZnONPs at $3378 \mathrm{~cm}^{-1}$ were due to the N-H stretching group of aliphatic primary amine. The peaks at 2948 and $2879 \mathrm{~cm}^{-1}$ represented the presence $\mathrm{N}-\mathrm{H}$ stretching group of amine salt, while absorption peaks at 1646 and $1457 \mathrm{~cm}^{-1}$ were attributed to the $\mathrm{C}=\mathrm{N}$ stretching group of imine/oxime and $\mathrm{C}=\mathrm{C}$ aromatic, respectively. The peaks at 1395 and 1204 $\mathrm{cm}^{-1}$ revealed the $\mathrm{O}-\mathrm{H}$ bending group of carboxylic acid and $\mathrm{C}-\mathrm{O}$ stretching group of alkyl aryl ether, respectively, whereas, the absorption peaks at 1078 and $1043 \mathrm{~cm}^{-1}$ were attributed to C-O stretching group primary alcohol and $\mathrm{S}=\mathrm{O}$ stretching group of sulfoxide, respectively. In agreement with the result of this study, previous studies reported the similar FTIR peaks for ZnONPs [54,55].

\subsubsection{XRD Analysis}

As shown in Figure 4, the crystalline nature and crystallite planes of two types of nanoparticles were justified based on the XRD spectrum peaks. Indeed, the typical distinct crystalline peaks were observed at $2 \theta=44.31^{\circ}, 64.45^{\circ}$, and $81.77^{\circ}$, which were assigned to (200), (220), and (311) reflections for green CSNPs (Figure 4C). On the contrary, Yen et al. [56] reported the peak of chitosan at $2 \theta=20.7^{\circ}$. In some cases, due to the transformation of structure into an amorphous nature, the peak disappears at $2 \theta$ and the emergence of broad bands at $2 \theta=35^{\circ}$ [57] XRD patterns of ZnONPs showed peaks at $2 \theta$ $=31.74^{\circ}, 34.40^{\circ}, 36.22^{\circ}, 47.51^{\circ}, 56.65^{\circ}, 62.83^{\circ}$, and $69.05^{\circ}$, which were assigned to $(100,002,101,102$, 110, 103, and 112) (Figure 4D). In the previous study, Ogunyemi et al. [19] reported the similar XRD diffraction peaks at $2 \theta=31.8^{\circ}, 34.5^{\circ}, 36.3^{\circ}, 47.6^{\circ}, 56.6^{\circ}, 62.9^{\circ}, 68.0^{\circ}, 72.6^{\circ}, 77.0^{\circ}, 81.4^{\circ}$, and $89.7^{\circ}$ of ZnONPs synthesized by using Matricaria chamomilla plant extracts. The diffraction peaks have been keenly indicated to the hexagonal structure of $\mathrm{ZnONPs}$. The narrow width of $\mathrm{ZnO}$ diffraction peaks in the XRD pattern proves that the samples were well crystallized [58]. Furthermore, the Sherrer's 
equation (particle size $=\mathrm{k} \lambda / \mathrm{b} \cos \theta$ ) revealed that the average particle size of CSNPs and ZnONP were 27.8 and $60.3 \mathrm{~nm}$, respectively. The current results are in agreement with previous studies, who observed the similar average size of CSNPs and ZnONPs through XRD analysis [31,59].

\subsection{Antibacterial Activity of CSNPs and ZnONPS}

\subsubsection{In Vitro Inhibitory Effect on the Growth of Xoo}

The results from this study indicated that the growth of Xoo strain GZ 0005 on the NA medium was effectively inhibited by bulk chitosan, bulk ZnO, CSNPs, and ZnONPs, while a greater effect was observed in the latter two nanoparticles (Figure 5 and Table 1). Indeed, CSNPs at the final concentration of $4.0,8.0$, and $16 \mu \mathrm{g} / \mathrm{mL}$ showed a mean inhibitory area of 2.1,2.3, and $2.4 \mathrm{~cm}$ compared with that of $0.9,1.2$, and $1.3 \mathrm{~cm}$ from the normal chitosan, respectively. Furthermore, the dried ZnONPs powder at the final concentration of 4.0,8.0, and $16 \mu \mathrm{g} / \mathrm{mL}$ showed an inhibitory area of 2.4, 2.6, and $2.9 \mathrm{~cm}$, compared with that of $1.4,1.5$, and $1.8 \mathrm{~cm}$ from bulk $\mathrm{ZnO}$, respectively. The inhibitory effect of CSNPs on the growth of Xoo in NB broth was determined by calculating the rate of inhibition in optical density (OD) at 600. Indeed, compared to the negative control, CSNPs at the final concentration of $4.0,8.0$, and $16.0 \mu \mathrm{g} / \mathrm{mL}$ showed an inhibition rate of $86.28,86.76$, and $86.85 \%$, while ZnONPs at the final concentration of $4.0,8.0$, and $16.0 \mu \mathrm{g} / \mathrm{mL}$ showed an inhibition ratio of $59.39,73.93$, and 86.66\%, respectively (Figure 5 and Table 2).
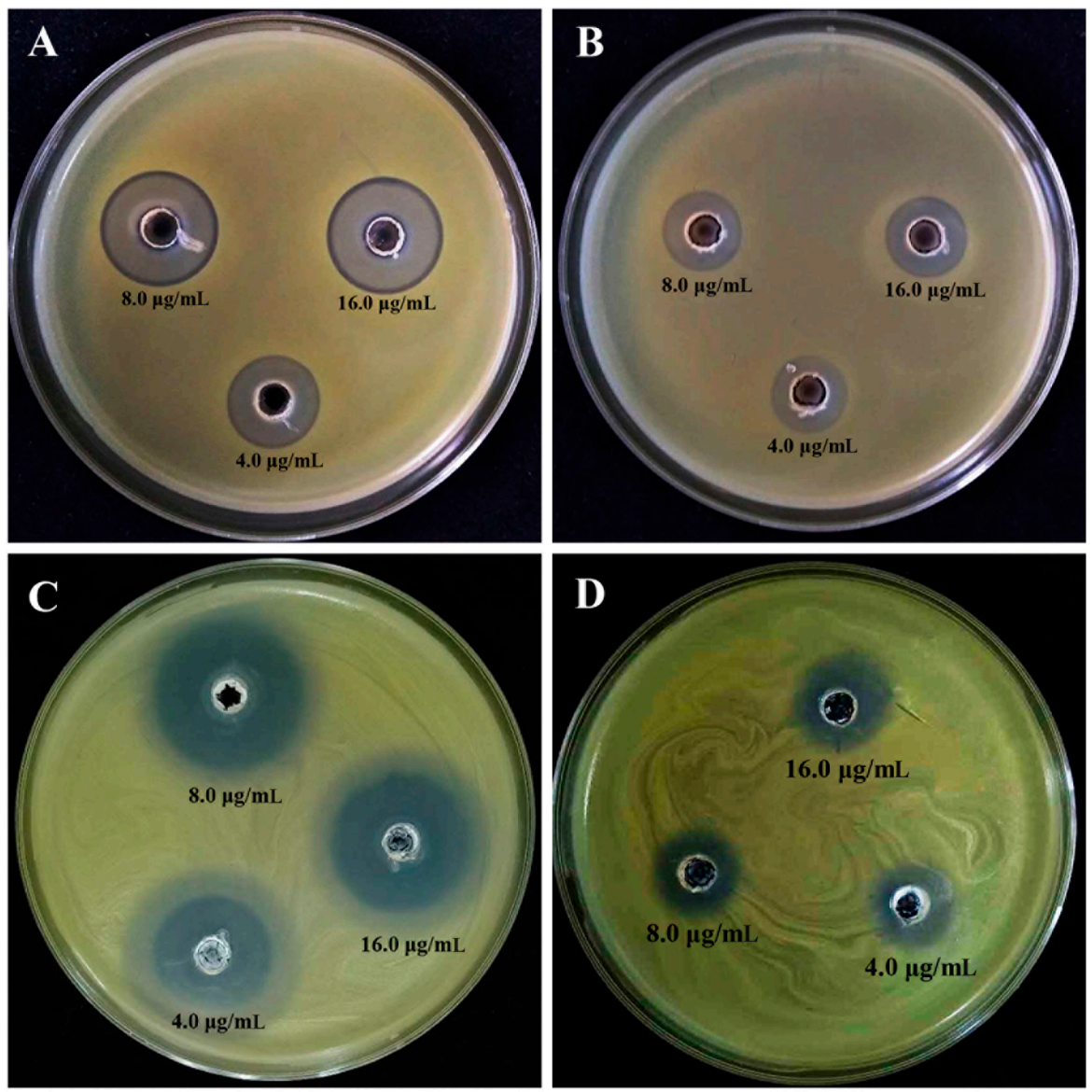

Figure 5. The in vitro inhibitory effect of (A) CSNPs, (B) bulk CS, (C) ZnONPs, and (D) bulk ZnO on the growth of Xanthomonas oryzae pv. oryzae strain GZ0005 following $24 \mathrm{~h}$ of incubation at $30{ }^{\circ} \mathrm{C}$. 
Table 1. The inhibitory effect of bulk chitosan (CS), chitosan nanoparticles (CSNPs), bulk ZnO, and zinc oxide nanoparticles (ZnONPs) on the growth of Xanthomonas oryzae pv. oryzae strain GZ0005 in nutrient agar plates.

\begin{tabular}{cc}
\hline Treatments & Inhibition Zone (cm) \\
\hline Xoo+ & \\
\hline Bulk CS $(4 \mu \mathrm{g} / \mathrm{mL})$ & $0.9 \pm 0.15^{\mathrm{b}}$ \\
Bulk CS $(8 \mu \mathrm{g} / \mathrm{mL})$ & $1.2 \pm 0.26^{\mathrm{b}}$ \\
Bulk CS $(16 \mu \mathrm{g} / \mathrm{mL})$ & $1.3 \pm 0.42^{\mathrm{b}}$ \\
\hline Xoo+ & \\
\hline CSNPs $(4 \mu \mathrm{g} / \mathrm{mL})$ & $2.1 \pm 0.42^{\mathrm{a}}$ \\
CSNPs $(8 \mu \mathrm{g} / \mathrm{mL})$ & $2.3 \pm 0.21^{\mathrm{a}}$ \\
CSNPs $(16 \mu \mathrm{g} / \mathrm{mL})$ & $2.4 \pm 0.26^{\mathrm{a}}$ \\
\hline Xoo+ & $1.4 \pm 0.16^{\mathrm{b}}$ \\
\hline Bulk ZnO $(4 \mu \mathrm{g} / \mathrm{mL})$ & $1.5 \pm 0.16^{\mathrm{b}}$ \\
Bulk ZnO $(8 \mu \mathrm{g} / \mathrm{mL})$ & $1.8 \pm 0.16^{\mathrm{b}}$ \\
Bulk ZnO $(16 \mu \mathrm{g} / \mathrm{mL})$ & \\
\hline Xoo+ & $2.4 \pm 0.21^{\mathrm{a}}$ \\
\hline ZnONPs $(4 \mu \mathrm{g} / \mathrm{mL})$ & $2.6 \pm 0.21^{\mathrm{a}}$ \\
ZnONPs $(8 \mu \mathrm{g} / \mathrm{mL})$ & $2.9 \pm 0.10^{\mathrm{a}}$ \\
\hline ZnONPs $(16 \mu \mathrm{g} / \mathrm{mL})$ &
\end{tabular}

Bulk chitosan and chitosan nanoparticles were dissolved in acetic acid, while bulk $\mathrm{ZnO}$ and zinc oxide nanoparticles were dissolved in ethylene glycol. The inhibition zones are represented as the means \pm standard error of at least three independent experiments. Different letters within one column indicate significant differences between treatments $(p \leq 0.05)$

Table 2. The in vitro inhibitory effect of chitosan nanoparticles (CSNPs) and zinc oxide nanoparticles (ZnONPs) at different concentrations $(4,8$, and $16 \mu \mathrm{g} / \mathrm{mL})$ on the growth, biofilm formation, and motility of Xanthomonas oryzae pv. oryzae strain GZ0005.

\begin{tabular}{|c|c|c|c|}
\hline Treatments & Bacterial Growth & Biofilm Formation & Motility (mm) \\
\hline Xoo & $1.65 \pm 0.02^{\mathrm{a}}$ & $1.13 \pm 0.03^{a}$ & $18.7 \pm 0.02^{a}$ \\
\hline Xoo + CSNPs $(4 \mu \mathrm{g} / \mathrm{mL})$ & $0.14 \pm 0.00^{b}$ & $0.56 \pm 0.05^{b}$ & $16.7 \pm 0.47^{b}$ \\
\hline Xoo + CSNPs $(8 \mu \mathrm{g} / \mathrm{mL})$ & $0.14 \pm 0.00^{b}$ & $0.43 \pm 0.02 b c$ & $15.0 \pm 0.82^{c}$ \\
\hline Xoo + CSNPs $(16 \mu \mathrm{g} / \mathrm{mL})$ & $0.14 \pm 0.00^{b}$ & $0.34 \pm 0.02^{c}$ & $12.7 \pm 0.94^{\mathrm{d}}$ \\
\hline Xoo + ZnONPs $(4 \mu \mathrm{g} / \mathrm{mL})$ & $0.67 \pm 0.02^{b}$ & $0.42 \pm 0.01^{b}$ & $16.2 \pm 0.47^{b}$ \\
\hline Xoo $+\mathrm{ZnONPs}(8 \mu \mathrm{g} / \mathrm{mL})$ & $0.43 \pm 0.02^{c}$ & $0.34 \pm 0.00 \mathrm{bc}$ & $17.3 \pm 0.82^{c}$ \\
\hline Xoo + ZnONPs $(16 \mu \mathrm{g} / \mathrm{mL})$ & $0.22 \pm 0.04^{\mathrm{d}}$ & $0.27 \pm 0.00^{d}$ & $14.5 \pm 0.82^{\mathrm{d}}$ \\
\hline
\end{tabular}

Chitosan nanoparticles were dissolved in acetic acid, while zinc oxide nanoparticles were dissolved in ethylene glycol. Bacterial growth and biofilm formation were determined by measuring the value of $\mathrm{OD}_{600}$ and $\mathrm{OD}_{570}$, respectively. Different letters within one column indicate significant differences between treatments $(p \leq 0.05)$.

In agreement with several previous reports $[17,23]$, the greater antibacterial activity could be achieved by the combination of nanoparticles with bulk chitosan and a heavy metal salt. Furthermore, there was no significant difference in the inhibitory zone on the NA medium between two types of nanoparticles, CSNPs and ZnONPs. However, CSNPs showed a greater inhibition on the growth of Xoo in NB broth compared to that of ZnONPs, indicating that Xoo strain GZ 0005 was more sensitive to CSNPs than to ZnONPs. As described in our previous studies, the biosynthesized silver nanoparticles showed promising antibacterial activity against rice pathogen Xoo [16,17]. On the other hand, CSNPs seem to be also safer than metallic NPs e.g., silver, copper, Zinc, etc. [19,60,61], due to the absence of the heavy metal ion, which poses a potential risk to plant growth and microbial activity in soils. In agreement with the result of this study, Li et al. [22] reported the antibacterial activity of chitosan $/ \mathrm{TiO}_{2}$ nanocomposite against Xoo. However, it can be inferred from this study that two types 
of nanoparticles, in particular, CSNPs, have a good prospect to be used as antibacterial agents again rice bacterial pathogen.

\subsubsection{Inhibition of Biofilm Formation and Motility Swimming}

The results from this study indicated that the $\mathrm{OD}_{570}$ value of Xoo strain GZ 0005 was 1.13 after $48 \mathrm{~h}$ of incubation, while the diameter of migration areas was $18.7 \mathrm{~mm}$ after 3 days of incubation in the absence of the two biosynthesized nanoparticles. However, biofilm formation and motility swimming of Xoo strain GZ 0005 were significantly reduced by the two biosynthesized nanoparticles. Indeed, CSNPs at the concentration of $4.0,8.0$, and $16.0 \mu \mathrm{g} / \mathrm{mL}$ caused a $50.44 \%, 61.91 \%$, and $69.91 \%$, respectively, reduction in the $\mathrm{OD}_{570}$ value, and a $10.7 \%, 19.8 \%$, and $32.1 \%$, respectively, reduction in the diameter of migration areas of Xoo strain GZ 0005 (Figure 6 and Table 2). Similarly, ZnONPs at the concentration of $4.0,8.0$, and $16.0 \mu \mathrm{g} / \mathrm{mL}$ caused a $62.83 \%, 69.91 \%$, and $76.10 \%$, respectively, reduction in the $\mathrm{OD}_{570}$ value, and a $5.3 \%, 14.4 \%$, and $25.1 \%$, respectively, inhibition in the diameter of migration areas of Xoo strain GZ 0005 compared with the control after $48 \mathrm{~h}$ of incubation (Figure 6 and Table 2).

(a) The effects of CSNPs and ZnONPs on the growth of Xanthomonas oryzae pv. oryzae strain GZ 0005
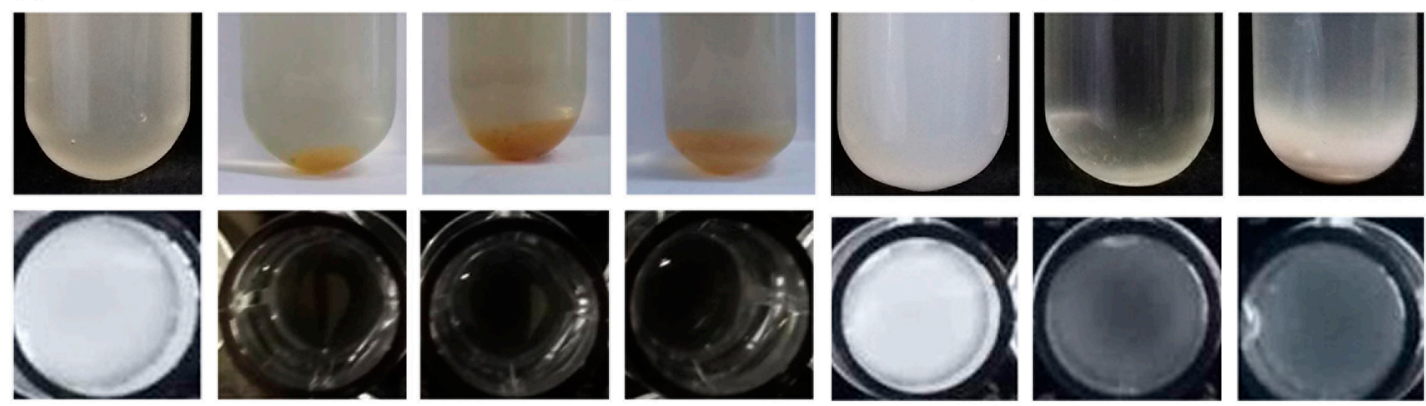

(b) The effects of CSNPs and ZnONPs on the biofilm formation
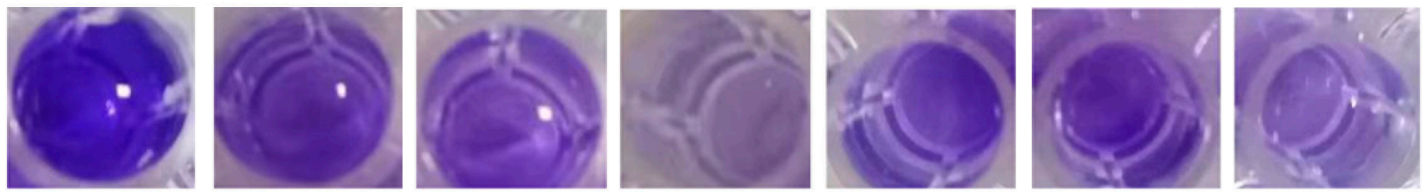

(c) The effects of CSNPs and ZnONPs on the motility swimming

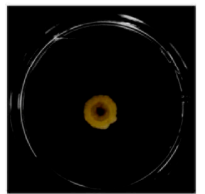

Control

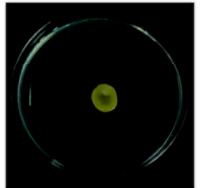

$4 \mu \mathrm{g} / \mathrm{mL}$

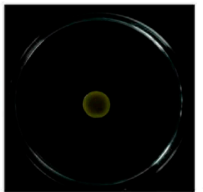

$8 \mu \mathrm{g} / \mathrm{mL}$

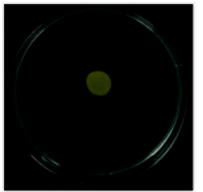

$16 \mu \mathrm{g} / \mathrm{mL}$

CSNPs

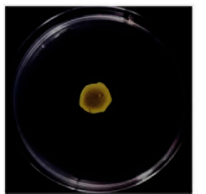

$4 \mu \mathrm{g} / \mathrm{mL}$

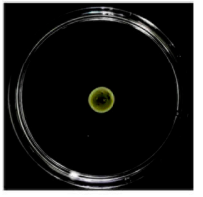

$8 \mu \mathrm{g} / \mathrm{mL}$

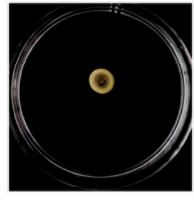

$16 \mu \mathrm{g} / \mathrm{mL}$

ZnONPs

Figure 6. The inhibitory effects of CSNPs and ZnONPs at different concentrations $(4,8$, and $16 \mu \mathrm{g} / \mathrm{mL})$ on (a) growth, (b) biofilm formation, and (c) motility swimming of Xanthomonas oryzae pv. oryzae strain GZ 0005 .

In general, this result indicated that the inhibitory effect in biofilm formation and motility swimming correlated positively with the concentration of two types of nanoparticles. The biofilms and motility swimming was able to protect the bacteria from immune responses by the host and contribute to bacterial resistance during host-pathogen interaction [62]. In agreement with the result of this study, de Paz et al. [63] reported the antimicrobial effect of chitosan nanoparticles on Streptococcus mutans biofilms, Tamara et al. [64] proposed that chitosan nanoparticles might have an impact on the pathways involved in the regulation of motility and biofilm formation, Lee et al. [65] indicated that 
$\mathrm{ZnO}$ nanoparticles could inhibit biofilm formation and virulence factor production of Pseudomonas aeruginosa. Therefore, the antibacterial activity of two types of nanoparticles against Xoo strain GZ 0005 may, at least partially, attribute to their inhibition in biofilm formation ability and motility swimming.

\subsubsection{TEM Observation of Cell Damage}

TEM observation of Xoo strain GZ 0005 showed an intact and clear cell wall with an evenly dispersed cell content that corresponds to the proteins, DNA and cytoplasmic content of the bacterial cells in the absence of the two biosynthesized nanoparticles CSNPs and ZnONPs. In contrast, microscopic images of Xoo cells treated with the biosynthesized CSNPs and ZnONPs at the final concentration of $16.0 \mu \mathrm{g} / \mathrm{mL}$ showed extensive destruction of cell walls compared to the negative control treated with distilled water. Indeed, the synthesized nanoparticles not only make the cell wall and cytoplasmic membrane became wrinkled, broken, and abnormal, but also caused the leakage of nutrients and nucleic materials, resulting in bacterial death (Figure 7).

(I) TEM observations of the damaged membrane of Xanthomonas oryzae pv. oryzae strain GZ0005
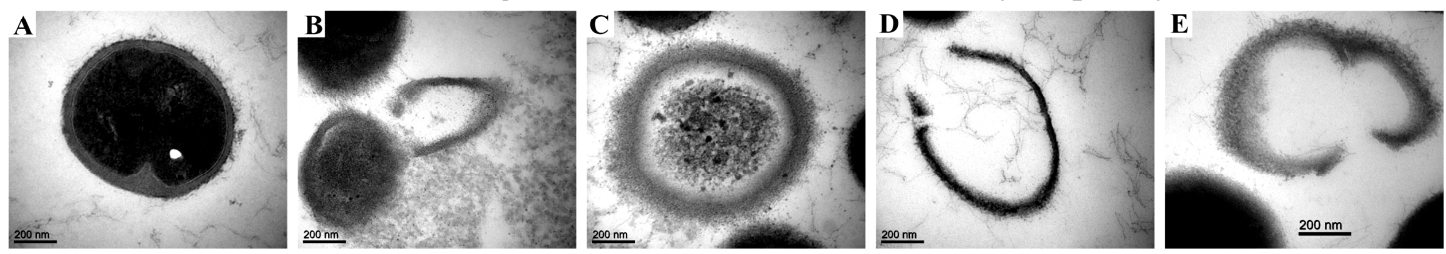

(II) Flow cytometry observations of Xanthomonas oryzae pv. oryzae strain GZ0005
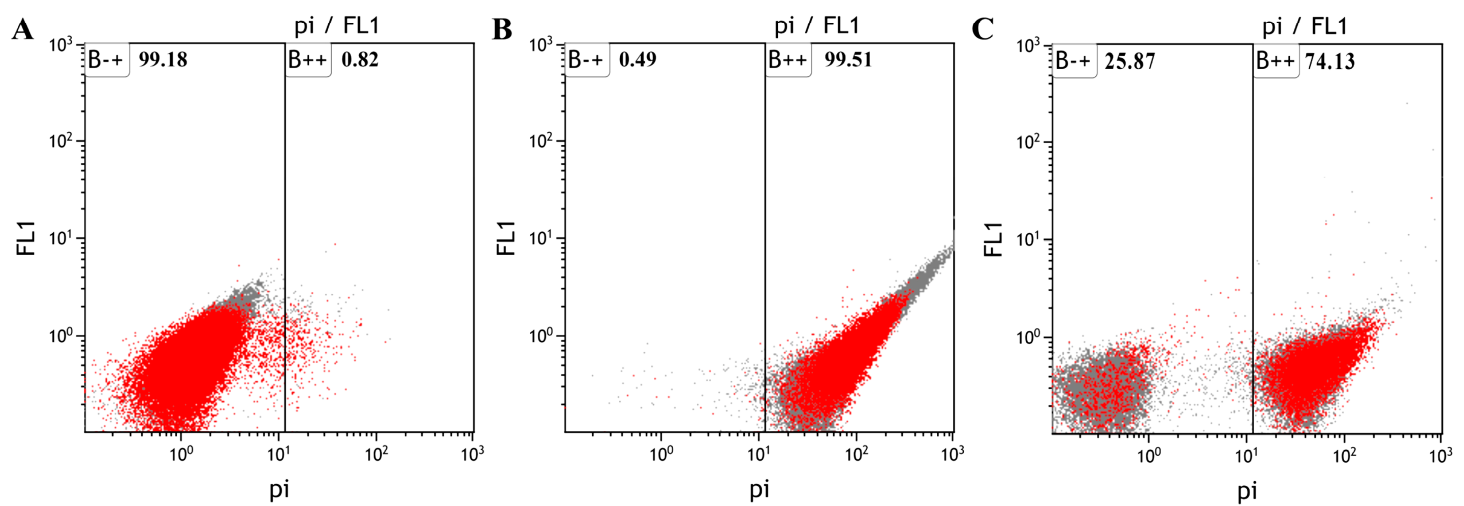

(III) Formation of ROS in Xanthomonas oryzae pv. oryzae strain GZ 0005
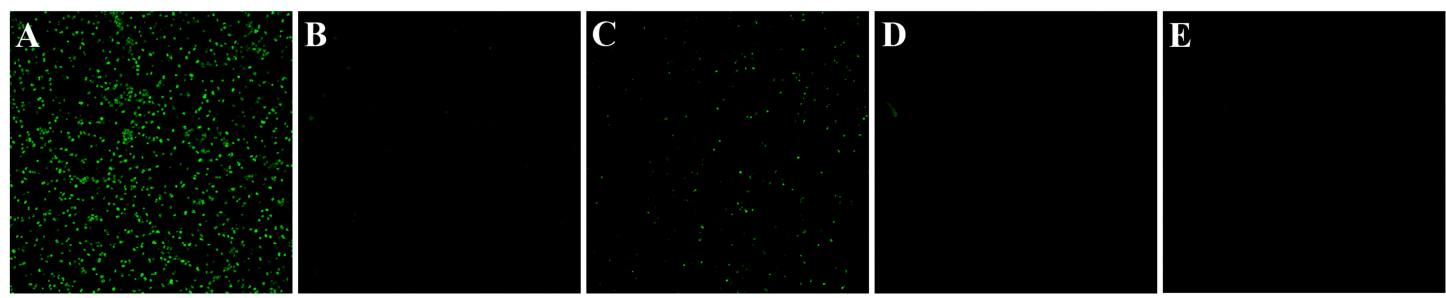

Figure 7. (I) TEM observations of the damaged membrane of Xanthomonas oryzae pv. oryzae strain GZ0005 treated with (A) sterile water, (B,C) CSNPs at $16 \mu \mathrm{g} / \mathrm{mL}$, and (D,E) ZnONPs at $16 \mu \mathrm{g} / \mathrm{mL}$. (II) Flow cytometry observations of Xanthomonas oryzae pv. oryzae strain GZ0005 cells after incubation with (A) sterile water, (B) CSNPs at $16 \mu \mathrm{g} / \mathrm{mL}$, and (C) ZnONPs at $16 \mu \mathrm{g} / \mathrm{mL}$. (III) Formation of ROS in Xanthomonas oryzae pv. oryzae strain GZ 0005 cells. (A) $4 \mathrm{~h}$ of incubation with CSNPs, (B) rotenone was added before $4 \mathrm{~h}$ of incubation with CSNPs, (C) $4 \mathrm{~h}$ of incubation with ZnONPs, (D) rotenone was added before $4 \mathrm{~h}$ of incubation with ZnONPs, and (E) $4 \mathrm{~h}$ of incubation with sterile water.

In agreement with the result of this study, the damage of chitosan and zinc oxide nanoparticle to bacterial cells has been well studied [66-68]. In addition, many studies have reported that the 
primary mechanism for the inhibitory effect may be mainly due to the interaction between the positive charges of nanoparticles and the negatively charged compounds in the bacterial cell wall, which caused the penetration of nanoparticles into the bacterial cells, increasing membrane permeability, and intracellular flow [69-72]. Therefore, it could be suggested that the antibacterial activity of two nanoparticles against Xoo strain GZ 0005 may be, at least partially, attributed to the destruction of the cell wall, which is an essential structure for the life of bacteria.

\subsubsection{FC Observation of the Apoptosis of Xoo Cells}

In addition to microscopic images of bacterial cells, a rapid and accurate assessment of cell damage was also observed in FC analysis using the propidium iodide (PI), which is a type of fluorochrome that can pass through damaged or dead cells, while the DNA stain was detected using ultraviolet rays. In agreement with the result of TEM observation, result from this study indicated that the two biosynthesized nanoparticles CSNPs and ZnONPs markedly increased the apoptosis of Xoo cells to $99.51 \%$ and $74.13 \%$, respectively, compared to $0.82 \%$ for the negative control treated with distilled water (Figure 7). Collectively, the data presented cell injury or death when bacteria were treated with the CSNPs and ZnONPs.

In agreement with the result of this study, cell membrane damage and promoted flowage was observed in Escheria coli following the treatment with nanoparticles and detection by FC analysis [73]. Additionally, Parida et al. [47] reported high apoptosis in cancer cells, which were exposed to different concentrations of chitosan nanoparticles. Furthermore, this result indicated that CSNPs has a greater effect on cell damage than that of ZnONPs, which is consistent with their inhibitory effect on the growth of Xoo strain GZ 0005 when incubating the bacteria in NB broth. Thus, it can be inferred that the antibacterial activity of the two biosynthesized nanoparticles CSNPs and ZnONPs against Xoo strain GZ 0005 may, at least partially, due to apoptosis of bacterial cells.

\subsubsection{CLSM Observation of ROS Generation}

Generation of reactive oxygen species (ROS) in Xoo strain GZ 0005 cells was determined based on CLSM observation of the intensity of the fluorescence after $4 \mathrm{~h}$ of incubation. Results from this study indicated that no obvious fluorescence was observed in bacterial cells in the negative control treated with sterile water. Furthermore, a little fluorescence was observed in Xoo strain GZ 0005 cells treated with $16.0 \mu \mathrm{g} / \mathrm{mL}$ of ZnONPs, while a lot of fluorescence was observed in Xoo strain GZ 0005 cells treated with $16.0 \mu \mathrm{g} / \mathrm{mL}$ of CSNPs (Figure 7). However, all fluorescence disappeared when the ROS inhibitor rotenone was applied in Xoo strain GZ 0005 cells before treatment with $16.0 \mu \mathrm{g} / \mathrm{mL}$ of the two biosynthesized nanoparticles CSNPs and ZnONPs (Figure 7).

In agreement with the result of this study, Banerjee et al. [74] found that chitosan-Ag nanocomposite was able to generate ROS in E. coli cells. The formation of ROS promotes the oxidative stress in the cells, which may in turn induce cell damage, causing cell lysis or distortion of bacterial membranes, resulting in the leakage of DNA and protein, even bacterial death [75]. Indeed, some studies have indicated that the antibacterial activity of ZnONPs could be due to the generation of ROS on oxides surfaces, which induced significant morphological changes and outflow in bacterial cells $[66,76]$. On the other hand, rotenone has been regarded as a scavenger of the electron transport chains in mitochondria, which is an essential site in the generation of ROS [77], this explains why a significant decrease in ROS content by the rotenone. Our results indicated that the strong antibacterial activity of the two biosynthesized nanoparticles, in particular, CSNPs was, at least partially, due to the generation of ROS.

\section{Conclusions}

In conclusion, this study successfully biosynthesized CSNPs and ZnONPs, which showed a stronger inhibitory effect on the growth of rice pathogenic bacteria Xoo compared to that of bulk chitosan or bulk $\mathrm{ZnO}$, respectively. Furthermore, the two synthesized nanoparticles with strong antibacterial activity were characterized by the analysis of UV-Vis spectroscopy, XRD, and FTIR as well 
as TEM and SEM observation. In addition, the antibacterial activity of two types of the nanoparticles may be able to, at least partially, be attributed to apoptosis, generation of ROS, reduction in biofilm formation and swimming, destruction or disintegration of the cell walls, and leakage of the intracellular contents, which eventually resulted in cell death. Overall, it could be concluded from this study that the two synthesized nanoparticles particularly CSNPs have a great potential to suppress Xoo infections in rice.

Author Contributions: Conceptualization, Y.A. and M.L.; methodology, B.L.; software, T.A.; validation, S.O.O., T.A., H.F., and A.A.; formal analysis, Y.A.; investigation, C.Y. and Y.Y.; resources, J.C.; data curation, S.O.O.; writing-original draft preparation, Y.A. and T.A.; writing—review and editing, T.A.; visualization, B.L.; supervision, B.L.; project administration, B.L.; funding acquisition, B.L. All authors have read and agreed to the published version of the manuscript.

Funding: The work is partially supported by Zhejiang Provincial Natural Science Foundation of China (LZ19C140002), National Natural Science Foundation of China (31872017, 32072472, 31571971, 31801787, 31901925), Shanghai Agriculture Applied Technology Development Program (2019-02-08-00-08-F01150), Zhejiang Provincial Project (2017C02002, 2019C02006, 2020C02006), National Key Research and Development Program of China (2018YFD0300900, 2017YFD0201104), Key Scientific Technological Project of Ningbo (2016C11017,2019B10004), the Fundamental Research Funds for the Central Universities, Dabeinong Funds for Discipline Development and Talent Training in Zhejiang University, State Key Laboratory for Managing Biotic and Chemical Treats to the Quality and Safety of Agro-products (2010DS700124-ZZ1907).

Conflicts of Interest: The authors declare no conflict of interest.

\section{References}

1. Bora, P.S.L.; Baruah, K.P.A.; Talukdar, R.B.K.; Kataky, L.; Phukan, A. Review on Bacterial Blight of rice caused by Xanthomonas oryzae pv. oryzae: Different management approaches and role of Pseudomonas fluorescens as a potential biocontrol agent. Int. J. Curr. Microbiol. Appl. Sci. 2017, 6, 982-1005. [CrossRef]

2. Ahmed, S.; Annu; Chaudhry, S.A.; Ikram, S. A review on biogenic synthesis of $\mathrm{ZnO}$ nanoparticles using plant extracts and microbes: A prospect towards green chemistry. J. Photochem. Photobiol. B Biol. 2017, 166, 272-284. [CrossRef]

3. Singh, A.; Singh, N.; Hussain, I.; Singh, H.; Yadav, V.; Singh, S. Green synthesis of nano zinc oxide and evaluation of its impact on germination and metabolic activity of Solanum lycopersicum. J. Biotechnol. 2016, 233, 84-94. [CrossRef]

4. Baek, S.; Joo, S.H.; Blackwelder, P.; Toborek, M. Effects of coating materials on antibacterial properties of industrial and sunscreen-derived titanium-dioxide nanoparticles on Escherichia coli. Chemosphere 2018, 208, 196-206. [CrossRef]

5. Pomastowski, P.; Król-Górniak, A.; Railean-Plugaru, V.; Buszewski, B. Zinc Oxide Nanocomposites-Extracellular Synthesis, Physicochemical Characterization and Antibacterial Potential. Materials 2020, 13, 4347. [CrossRef]

6. Mittal, A.K.; Chisti, Y.; Banerjee, U.C. Synthesis of metallic nanoparticles using plant extracts. Biotechnol. Adv. 2013, 31, 346-356. [CrossRef]

7. Basnet, P.; Chanu, T.I.; Samanta, D.; Chatterjee, S. A review on bio-synthesized zinc oxide nanoparticles using plant extracts as reductants and stabilizing agents. J. Photochem. Photobiol. B Biol. 2018, 183, 201-221. [CrossRef] [PubMed]

8. Elwan, H.A.M.; ElNesr, S.S.; Mohany, M.; Al-Rejaie, S.S. The effects of dietary tomato powder (Solanum lycopersicum L.) supplementation on the haematological, immunological, serum biochemical and antioxidant parameters of growing rabbits. J. Anim. Physiol. Anim. Nutr. 2018, 103, 534-546. [CrossRef] [PubMed]

9. Friedman, M. Tomato Glycoalkaloids: Role in the Plant and in the Diet. J. Agric. Food Chem. 2002, 50, 5751-5780. [CrossRef] [PubMed]

10. Rodriguez, J.; Rios, D.; Rodriguez, E.; Diaz, C. Physico-Chemical Changes During Ripening of Conventionally, Ecologically and Hydroponically Cultivated Tyrlain (TY 10016) Tomatoes. Int. J. Agric. Res. 2006, 1, 452-461. [CrossRef]

11. Nagaonkar, D.; Gaikwad, S.; Rai, M. Catharanthus roseus leaf extract-synthesized chitosan nanoparticles for controlled in vitro release of chloramphenicol and ketoconazole. Colloid Polym. Sci. 2015, 293, 1465-1473. [CrossRef] 
12. Sutradhar, P.; Saha, M. Green synthesis of zinc oxide nanoparticles using tomato (Lycopersicon esculentum) extract and its photovoltaic application. J. Exp. Nanosci. 2015, 11, 314-327. [CrossRef]

13. Wang, L.; Hu, C.; Shao, L. The antimicrobial activity of nanoparticles: Present situation and prospects for the future. Int. J. Nanomed. 2017, 12, 1227-1249. [CrossRef] [PubMed]

14. Predoi, D.; Iconaru, S.L.; Predoi, D. Fabrication of Silver- and Zinc-Doped Hydroxyapatite Coatings for Enhancing Antimicrobial Effect. Coatings 2020, 10, 905. [CrossRef]

15. Li, B.; Wang, X.; Chen, R.; Huangfu, W.; Xie, G. Antibacterial activity of chitosan solution against Xanthomonas pathogenic bacteria isolated from Euphorbia pulcherrima. Carbohydr. Polym. 2008, 72, 287-292. [CrossRef]

16. Abdallah, Y.; Ogunyemi, S.O.; Abdelazez, A.; Zhang, M.; Hong, X.; Ibrahim, E.; Hossain, A.; Fouad, H.; Li, B.; Chen, J. The Green Synthesis of MgO Nano-Flowers Using Rosmarinus officinalis L. (Rosemary) and the Antibacterial Activities against Xanthomonas oryzae pv. oryzae. Bio Med. Res. Int. 2019, 2019, 1-8. [CrossRef] [PubMed]

17. Ibrahim, E.; Fouad, H.; Zhang, M.; Zhang, Y.; Qiu, W.; Yan, C.; Li, B.; Mo, J.; Chen, J. Biosynthesis of silver nanoparticles using endophytic bacteria and their role in inhibition of rice pathogenic bacteria and plant growth promotion. RSC Adv. 2019, 9, 29293-29299. [CrossRef]

18. Ahmed, T.; Shahid, M.; Noman, M.; Niazi, M.B.K.; Mahmood, F.; Manzoor, I.; Zhang, Y.; Li, B.; Yang, Y.; Yan, C.; et al. Silver Nanoparticles Synthesized by Using Bacillus cereus SZT1 Ameliorated the Damage of Bacterial Leaf Blight Pathogen in Rice. Pathogens 2020, 9, 160. [CrossRef]

19. Ogunyemi, S.O.; Abdallah, Y.; Zhang, M.; Fouad, H.; Hong, X.; Ibrahim, E.; Masum, M.I.; Hossain, A.; Mo, J.; $\mathrm{Li}, \mathrm{B}$. Green synthesis of zinc oxide nanoparticles using different plant extracts and their antibacterial activity against Xanthomonas oryzae pv. oryzae. Artif. Cells Nanomed. Biotechnol. 2019, 47, 341-352. [CrossRef]

20. Maruyama, C.R.; Guilger, M.; Pascoli, M.; Bileshy-José, N.; Abhilash, P.; Fraceto, L.F.; De Lima, R. Nanoparticles Based on Chitosan as Carriers for the Combined Herbicides Imazapic and Imazapyr. Sci. Rep. 2016, 6, 19768. [CrossRef]

21. Campos, E.V.R.; Proença, P.L.F.; Oliveira, J.L.; Melville, C.C.; Della Vechia, J.F.; De Andrade, D.J.; Fraceto, L.F. Chitosan nanoparticles functionalized with $\beta$-cyclodextrin: A promising carrier for botanical pesticides. Sci. Rep. 2018, 8, 2067. [CrossRef] [PubMed]

22. Wang, W.; Hao, X.; Chen, S.; Yang, Z.; Wang, C.; Yan, R.; Zhang, X.; Liu, H.; Shao, Q.; Guo, Z. pH-responsive Capsaicin@chitosan nanocapsules for antibiofouling in marine applications. Polymer 2018, 158, 223-230. [CrossRef]

23. Li, B.; Zhang, Y.; Yang, Y.; Qiu, W.; Wang, X.; Liu, B.; Wang, Y.; Sun, G.-C. Synthesis, characterization, and antibacterial activity of chitosan/ $/ \mathrm{TiO}_{2}$ nanocomposite against Xanthomonas oryzae pv. oryzae. Carbohydr. Polym. 2016, 152, 825-831. [CrossRef] [PubMed]

24. Agnihotri, S.A.; Mallikarjuna, N.N.; Aminabhavi, T. Recent advances on chitosan-based micro- and nanoparticles in drug delivery. J. Control. Release 2004, 100, 5-28. [CrossRef]

25. Zhang, C.; Qu, G.; Sun, Y.; Yang, T.; Yao, Z.; Shen, W.; Shen, Z.; Ding, Q.; Zhou, H.; Ping, Q. Biological evaluation of N-octyl-O-sulfate chitosan as a new nano-carrier of intravenous drugs. Eur. J. Pharm. Sci. 2008, 33, 415-423. [CrossRef]

26. Dube, A.; Nicolazzo, J.A.; Larson, I. Chitosan nanoparticles enhance the intestinal absorption of the green tea catechins (+)-catechin and (-)-epigallocatechin gallate. Eur. J. Pharm. Sci. 2010, 41, 219-225. [CrossRef]

27. Ghadi, A.; Mahjoub, S.; Tabandeh, F.; Talebnia, F. Synthesis and optimization of chitosan nanoparticles: Potential applications in nanomedicine and biomedical engineering. Casp. J. Intern. Med. 2014, 5, 156-161.

28. Yahya, E.B.; Jummaat, F.; Amirul, A.A.; Adnan, A.; Olaiya, N.; Abdullah, C.; Rizal, S.; Haafiz, M.M.; Khalil, H.A. A Review on Revolutionary Natural Biopolymer-Based Aerogels for Antibacterial Delivery. Antibiotics 2020, 9, 648. [CrossRef]

29. Sullivan, D.J.; Cruz-Romero, M.; Collins, T.; Cummins, E.; Kerry, J.P.; Morris, M.A. Synthesis of monodisperse chitosan nanoparticles. Food Hydrocoll. 2018, 83, 355-364. [CrossRef]

30. Zeng, Z.W.; Wang, J.J.; Xiao, R.Z.; Xie, T.; Zhou, G.L.; Zhan, X.R.; Wang, S.L. Recent advances of chitosan nanoparticles as drug carriers. Int. J. Nanomed. 2011, 6, 765-774. [CrossRef]

31. Anand, M.; Sathyapriya, P.; Maruthupandy, M.; Beevi, A.H. Synthesis of chitosan nanoparticles by TPP and their potential mosquito larvicidal application. Front. Lab. Med. 2018, 2, 72-78. [CrossRef]

32. Liu, T.; Wang, J.; Chi, F.; Tan, Z.; Liu, L. Development and Characterization of Novel Active Chitosan Films Containing Fennel and Peppermint Essential Oils. Coatings 2020, 10, 936. [CrossRef] 
33. Ahmed, T.; Noman, M.; Shahid, M.; Niazi, M.B.K.; Hussain, S.; Manzoor, N.; Wang, X.; Li, B. Green synthesis of silver nanoparticles transformed synthetic textile dye into less toxic intermediate molecules through LC-MS analysis and treated the actual wastewater. Environ. Res. 2020, 110142. [CrossRef] [PubMed]

34. Ahmed, T.; Shahid, M.; Noman, M.; Niazi, M.B.K.; Zubair, M.; Almatroudi, A.; Khurshid, M.; Tariq, F.; Mumtaz, R.; Li, B. Bioprospecting a native silver-resistant Bacillus safensis strain for green synthesis and subsequent antibacterial and anticancer activities of silver nanoparticles. J. Adv. Res. 2020, 24, 475-483. [CrossRef]

35. Hossain, A.; Abdallah, Y.; Ali, M.A.; Masum, M.M.I.; Li, B.; Sun, G.; Meng, Y.; Wang, Y.; An, Q. Lemon-Fruit-Based Green Synthesis of Zinc Oxide Nanoparticles and Titanium Dioxide Nanoparticles against Soft Rot Bacterial Pathogen Dickeya dadantii. Biomolecules 2019, 9, 863. [CrossRef]

36. Perez, C. Antibiotic assay by agar-well diffusion method. Acta Biol. Med. Exp. 1990, 15, 113-115.

37. Wiegand, I.; Hilpert, K.; Hancock, R.E.W. Agar and broth dilution methods to determine the minimal inhibitory concentration (MIC) of antimicrobial substances. Nat. Protoc. 2008, 3, 163-175. [CrossRef]

38. Zhang, L.; Xu, J.; Xu, J.; Zhang, H.; He, L.; Feng, J. TssB is essential for virulence and required for Type VI secretion system in Ralstonia solanacearum. Microb. Pathog. 2014, 74, 1-7. [CrossRef]

39. Raza, W.; Ling, N.; Yang, L.; Huang, Q.; Shen, Q. Response of tomato wilt pathogen Ralstonia solanacearum to the volatile organic compounds produced by a biocontrol strain Bacillus amyloliquefaciens SQR-9. Sci. Rep. 2016, 6, 24856. [CrossRef]

40. Sun, D.; Zhang, W.; Mou, Z.; Chen, Y.; Guo, F.; Yang, E.; Wang, W. Transcriptome Analysis Reveals Silver Nanoparticle-Decorated Quercetin Antibacterial Molecular Mechanism. ACS Appl. Mater. Interfaces 2017, 9, 10047-10060. [CrossRef]

41. Cai, L.; Chen, J.; Liu, Z.; Wang, H.; Yang, H.; Ding, W. Magnesium Oxide Nanoparticles: Effective Agricultural Antibacterial Agent Against Ralstonia solanacearum. Front. Microbiol. 2018, 9, 790. [CrossRef]

42. Applerot, G.; Lellouche, J.; Lipovsky, A.; Nitzan, Y.; Lubart, R.; Gedanken, A.; Banin, E. Understanding the Antibacterial Mechanism of $\mathrm{CuO}$ Nanoparticles: Revealing the Route of Induced Oxidative Stress. Small 2012, 8, 3326-3337. [CrossRef] [PubMed]

43. Oh, J.-W.; Chun, S.; Chandrasekaran, M. Preparation and In Vitro Characterization of Chitosan Nanoparticles and Their Broad-Spectrum Antifungal Action Compared to Antibacterial Activities against Phytopathogens of Tomato. Agronomy 2019, 9, 21. [CrossRef]

44. Ahamed, M.; Akhtar, M.J.; Kumar, S.; Khan, M.M.; Ahmad, J.; A Alrokayan, S. Zinc oxide nanoparticles selectively induce apoptosis in human cancer cells through reactive oxygen species. Int. J. Nanomed. 2012, 7, 845-857. [CrossRef] [PubMed]

45. Wanichwecharungruang, S.P. Chitosan-Nanoparticle as UV Filter and Carrier for Cosmetic Actives. In Technical Proceedings of the 2007 NSTI Nanotechnology Conference and Trade Show, Santa Clara, CA, USA, 20-24 May 2007; pp. 257-260.

46. Sharma, D.; Rajput, J.; Kaith, B.; Kaur, M.; Sharma, S. Synthesis of ZnO nanoparticles and study of their antibacterial and antifungal properties. Thin Solid Films 2010, 519, 1224-1229. [CrossRef]

47. Parida, U.K.; Rout, N.; Bindhani, B.K. In vitro properties of chitosan nanoparticles induce apoptosis in human lymphoma SUDHL-4 cell line. Adv. Biosci. Biotechnol. 2013, 4, 1118-1127. [CrossRef]

48. Ilk, S.; Saglam, N.; Özgen, M. Kaempferol loaded lecithin/chitosan nanoparticles: Preparation, characterization, and their potential applications as a sustainable antifungal agent. Artif. Cells Nanomed. Biotechnol. 2016, 45, 907-916. [CrossRef]

49. Fu, L.; Fu, Z. Plectranthus amboinicus leaf extract-assisted biosynthesis of ZnO nanoparticles and their photocatalytic activity. Ceram. Int. 2015, 41, 2492-2496. [CrossRef]

50. Sotelo-Boyás, M.; Valverde-Aguilar, G.; Plascencia-Jatomea, M.; Correa-Pacheco, Z.; Jiménez-Aparicio, A.; Solorza-Feria, J.; Barrera-Necha, L.; Bautista-Banos, S. Characterization of chitosan nanoparticles added with essential oils. in vitro effect on Pectobacterium carotovorum. Rev. Mex. Ing. Quim. 2015, 14, 589-599.

51. Ali, J.; Irshad, R.; Li, B.; Tahir, K.; Ahmad, A.; Shakeel, M.; Khan, N.U.; Khan, Z.U.H. Synthesis and characterization of phytochemical fabricated zinc oxide nanoparticles with enhanced antibacterial and catalytic applications. J. Photochem. Photobiol. B Biol. 2018, 183, 349-356. [CrossRef]

52. Senthilkumar, S.; Sivakumar, T. Green tea (Camellia sinensis) mediated synthesis of zinc oxide ( $\mathrm{ZnO})$ nanoparticles and studies on their antimicrobial activities. Int. J. Pharm. Pharm. Sci. 2014, 6, 461-465. 
53. Salehizadeh, H.; Hekmatian, E.; Sadeghi, M.; Kennedy, K.J. Synthesis and characterization of core-shell Fe3O4-gold-chitosan nanostructure. J. Nanobiotechnol. 2012, 10, 3. [CrossRef] [PubMed]

54. Hedayati, K. Fabrication and optical characterization of zinc oxide nanoparticles prepared via a simple sol-gel method. J. Nanostruct. 2015, 5, 395-401. [CrossRef]

55. Yedurkar, S.; Maurya, C.; Mahanwar, P. Biosynthesis of Zinc Oxide Nanoparticles Using Ixora Coccinea Leaf Extract-A Green Approach. Open J. Synth. Theory Appl. 2016, 5, 1-14. [CrossRef]

56. Yen, M.-T.; Yang, J.-H.; Mau, J.-L. Physicochemical characterization of chitin and chitosan from crab shells. Carbohydr. Polym. 2009, 75, 15-21. [CrossRef]

57. El Zowalaty, M.E.; Ibrahim, N.A.; Salama, M.; Shameli, K.; Usman, M.S.; Zainuddin, N. Synthesis, characterization, and antimicrobial properties of copper nanoparticles. Int. J. Nanomed. 2013, 8, 4467-4479. [CrossRef]

58. Gupta, A.; Srivastava, P.; Bahadur, L.; Amalnerkar, D.P.; Chauhan, R. Comparison of physical and electrochemical properties of $\mathrm{ZnO}$ prepared via different surfactant-assisted precipitation routes. Appl. Nanosci. 2014, 5, 787-794. [CrossRef]

59. Mahendra, C.; Murali, M.; Manasa, G.; Ponnamma, P.; Abhilash, M.; Lakshmeesha, T.; Satish, A.; Amruthesh, K.; Sudarshana, M. Antibacterial and antimitotic potential of bio-fabricated zinc oxide nanoparticles of Cochlospermum religiosum (L.). Microb. Pathog. 2017, 110, 620-629. [CrossRef]

60. Mishra, S.; Yang, X.; Ray, S.; Fraceto, L.F.; Singh, H. Antibacterial and biofilm inhibition activity of biofabricated silver nanoparticles against Xanthomonas oryzae pv. oryzae causing blight disease of rice instigates disease suppression. World J. Microbiol. Biotechnol. 2020, 36, 1-10. [CrossRef]

61. Majumdar, T.D.; Singh, M.; Thapa, M.; Dutta, M.; Mukherjee, A.; Ghosh, C.K. Size-dependent antibacterial activity of copper nanoparticles against Xanthomonas oryzae pv. oryzae-A synthetic and mechanistic approach. Colloid Interface Sci. Commun. 2019, 32, 100190. [CrossRef]

62. Bridier, A.; Briandet, R.; Thomas, V.; Dubois-Brissonnet, F. Resistance of bacterial biofilms to disinfectants: A review. Biofouling 2011, 27, 1017-1032. [CrossRef]

63. De Paz, L.E.C.; Resin, A.; Howard, K.A.; Sutherland, D.S.; Wejse, P.L. Antimicrobial Effect of Chitosan Nanoparticles on Streptococcus mutans Biofilms. Appl. Environ. Microbiol. 2011, 77, 3892-3895. [CrossRef] [PubMed]

64. Tamara, F.R.; Lin, C.; Mi, F.-L.; Ho, Y.-C. Antibacterial Effects of Chitosan/Cationic Peptide Nanoparticles. Nanomater. 2018, 8, 88. [CrossRef] [PubMed]

65. Lee, J.-H.; Kim, Y.-G.; Cho, M.H.; Lee, J. ZnO nanoparticles inhibit Pseudomonas aeruginosa biofilm formation and virulence factor production. Microbiol. Res. 2014, 169, 888-896. [CrossRef] [PubMed]

66. Tiwari, V.; Mishra, N.; Gadani, K.; Solanki, P.S.; Shah, N.A.; Tiwari, M. Mechanism of Anti-bacterial Activity of Zinc Oxide Nanoparticle Against Carbapenem-Resistant Acinetobacter baumannii. Front. Microbiol. 2018, 9 , 1218. [CrossRef] [PubMed]

67. Wang, Q.; Zuo, J.; Wang, Q.; Na, Y.; Gao, L.-P. Inhibitory effect of chitosan on growth of the fungal phytopathogen, Sclerotinia sclerotiorum, and sclerotinia rot of carrot. J. Integr. Agric. 2015, 14, 691-697. [CrossRef]

68. Xie, Y.; He, Y.; Irwin, P.L.; Jin, T.; Shi, X. Antibacterial Activity and Mechanism of Action of Zinc Oxide Nanoparticles against Campylobacter jejuni. Appl. Environ. Microbiol. 2011, 77, 2325-2331. [CrossRef]

69. Ai, H.; Wang, F.; Xia, Y.; Chen, X.; Lei, C. Antioxidant, antifungal and antiviral activities of chitosan from the larvae of housefly, Musca domestica L. Food Chem. 2012, 132, 493-498. [CrossRef]

70. Chang, S.-H.; Lin, H.-T.V.; Wu, G.-J.; Tsai, G.J. pH Effects on solubility, zeta potential, and correlation between antibacterial activity and molecular weight of chitosan. Carbohydr. Polym. 2015, 134, 74-81. [CrossRef]

71. Pilon, L.; Spricigo, P.C.; Miranda, M.; De Moura, M.R.; Assis, O.B.G.; Mattoso, L.H.; Ferreira, M.D. Chitosan nanoparticle coatings reduce microbial growth on fresh-cut apples while not affecting quality attributes. Int. J. Food Sci. Technol. 2014, 50, 440-448. [CrossRef]

72. Jin, T.; Sun, D.; Su, J.; Zhang, H.; Sue, H.-J. Antimicrobial Efficacy of Zinc Oxide Quantum Dots againstListeria monocytogenes, Salmonella Enteritidis, and Escherichia coli O157:H7. J. Food Sci. 2009, 74, M46-M52. [CrossRef] [PubMed]

73. Kumar, A.; Pandey, A.K.; Singh, S.S.; Shanker, R.; Dhawan, A. Engineered ZnO and TiO2 nanoparticles induce oxidative stress and DNA damage leading to reduced viability of Escherichia coli. Free Radic. Biol. Med. 2011, 51, 1872-1881. [CrossRef] [PubMed] 
74. Banerjee, M.; Mallick, S.; Paul, A.; Chattopadhyay, A.; Ghosh, S.S. Heightened Reactive Oxygen Species Generation in the Antimicrobial Activity of a Three Component Iodinated Chitosan-Silver Nanoparticle Composite. Langmuir 2010, 26, 5901-5908. [CrossRef] [PubMed]

75. Le Ouay, B.; Stellacci, F. Antibacterial activity of silver nanoparticles: A surface science insight. Nano Today 2015, 10, 339-354. [CrossRef]

76. Augustine, R.; Malik, H.N.; Singhal, D.K.; Mukherjee, A.; Malakar, D.; Kalarikkal, N.; Thomas, S. Electrospun polycaprolactone/ZnO nanocomposite membranes as biomaterials with antibacterial and cell adhesion properties. J. Polym. Res. 2014, 21, 1-17. [CrossRef]

77. Li, H.; Deng, Z.-Y.; Liu, R.; Loewen, S.A.; Tsao, R. Bioaccessibility, in vitro antioxidant activities and in vivo anti-inflammatory activities of a purple tomato (Solanum lycopersicum L.). Food Chem. 2014, 159, 353-360. [CrossRef]

Sample Availability: Samples of the compounds are available from the authors.

Publisher's Note: MDPI stays neutral with regard to jurisdictional claims in published maps and institutional affiliations.

(C) 2020 by the authors. Licensee MDPI, Basel, Switzerland. This article is an open access article distributed under the terms and conditions of the Creative Commons Attribution (CC BY) license (http://creativecommons.org/licenses/by/4.0/). 